\title{
The Lack Of Industrialization, The Limited Number Of Private Corporations, And The Retardation Of Management In Private Business Enterprises In Greece
}

John Theodore, JDT Management Consultants, USA

\begin{abstract}
The purpose of this article was to examine and evaluate how 1) the late arrival of industrialization in Greece and the subsequent de-industrialization of the country deterred the formation and expansion of private corporations and impeded the mergers of small private enterprises in creating larger ones in the corporate form of business and 2) how the limited presence of private corporations retarded the development of management. Corporations are created through a planned initial formation and/or through the mergers of smaller corporate and non-corporate entities, such as proprietorships, partnerships, and family-owned non-stock corporations. Subsequently, the ample factors of production within the corporation allow the formation of professional management and the principles of organization which result in advanced managerial and organizational performance.
\end{abstract}

Keywords: Industrialization; De-Industrialization; Organization Development; Organization Size; Organizational Structure; Organizational Levels; Departmentalization; Delegation; Span of Control; Chain And Line of Command; Managerial Education; Mergers

\section{INTRODUCTION}

e ndustrialization is the process of coordinating materials, persons, and machines to create finished products for the satisfaction of human needs. It includes the factory system, mechanization and automation, technology, scientific decision-making, division of labor, and large amounts of money in the form of investments and operating funds. Industrialization generates, supports, sustains, and develops the corporate form of business which possesses all the factors of production in abundance that are needed for the creation and development of professional management. Human beings existed for eons before the industrial revolution and were engaged in economic undertakings, but not on the scale to compare with what would emerge as a result of industrialization (Wren, 1994)

\section{INDUSTRIALIZATION}

Industrialization has never been a static process; on the contrary, it has been under the auspices of a continuing evolution of technology since its beginning (Gilll,1973), starting with textiles and then moving to railroads, shipping, aviation, electronics, and to the immense and complex areas that exist today. The failure of the Greek economy to apply continuing technology when industrialization started in the country in the 1960s resulted in the stagnation of the process and the subsequent de-industrialization of the nation.

\section{THE CORPORATION}

The corporation has the capacity to combine the capital, and thus the economic power of unlimited numbers of people. The corporate governance of corporations in advanced economies is entrusted to CEOs and other 
professional managers (Morck, 2007). In advanced economies, the corporation is the basis of prosperity and the best hope for the future of the rest of the world; the institution that set the style and pace for the latter part of the twentieth century is the corporation (Fabun, 1973). Private corporations are created through a planned initial formation and/or through the mergers of small corporate and non-corporate entities, such as proprietorships, partnerships, and family-owned non-stock corporations.

Another option in creating private corporations - which is currently of great importance for Greece - is the privatization of government corporations, a process that requires substantial effort to change the bureaucratic mentality of the management and create a modern and dynamic corporate modus operandi. A necessary condition of creating a market economy is that of the government transferring its ownership and control of factors of production to owners via the process of privatization, which is essential for improving market efficiency because only a robust private sector can shape the relations between supply and demand leading to better production and consumption decisions (Daniels, Radebaugh, \& Sullivan, 2009).

Mergers create larger size corporations which is a condition that allows the appearance, sustenance, and development of the principles of organization and the need for commensurate management education for the managers of such enterprises, thus preparing the merged organizations to attain managerial and organizational development (Palmer, Dunford, \& Akin, 2009). In creating mergers, the entering entities draw on both partners' strength and provide benefits that neither partner could have achieved alone (Pierce \& Newstromg, 2008).

\section{LARGE ORGANIZATIONAL SIZE}

Organizational size is the structural property of the organization and can be defined in terms of space volume, sales volume, net assets, customers, or the number of persons employed in the organization. In this study, organizational size denotes the number of employees and managers employed in organizations. The size of an enterprise affects its organizational structure which subsequently impacts the levels of the structure and its departmentalization. Large organizations tend to have more specialization, departmentalization, centralization, and rules and regulations than do small organizations. It is important to note that management should avoid complexity as the size of the organization increases because complexity can lead to managerial and organizational problems (Kreitner, 2007). The element of organizational complexity is introduced with size (Bennis, 2009).

\section{SUFFICIENT ORGANIZATIONAL STRUCTURE AND DESIGN}

Organizational structure is defined as a stable framework which depicts how the human and non-human elements in it are arranged and grouped. It is based on the organization's mission, goals, and objectives. The number, diversity, and complexity of an organization's goals should play an important role in decisions about how it should be structured or designed. The terms structure and design are often used synonymously but they are not the same. Design refers to structure and the elements that support it - process and lateral capacity, reward system, and people practices (Anderson, 2010). Non-human elements include positions, job duties, lines of authority, formal patterns of activities, and relationships that connect the various constituent parts of the structure, such as hierarchical levels, divisions, departments, etc. Within departments, the respective managers and employees (the human element) form the span of control, chain and unity of command, and delegation. Within the organizational structure, and specifically within its divisions and departments, activities are being performed on a continuous basis, most of the time. Non-routine activities also occur in some cases, as demanded by contingencies.

\section{REQUIRED ORGANIZATIONAL LEVELS}

If there is large organizational size and a sufficient organizational structure, three levels in the organizational hierarchy are formed: top, middle, and lower/operational. In the top level reside the executives whose function is to direct the strategic elements of the organization. This level is the leadership level because the executives are monitoring the external environment and move the organization toward any direction that environmental factors dictate. This results in the creation of commensurate strategies that serve as the forces that guide the organization toward the desired path. Middle managers supervise first-line manages and are responsible for finding the best way to use resources to achieve organizational goals (Jones \& George, 2007). 
The middle level performs strategic functions, too, but such functions are for short term purpose or tactical functions. Middle managers are expected to translate the delegated strategies from the leadership level into tactical actions that include specific goals and applications.

Because of their large size, sufficient organizational structure, and the required organizational levels, corporations precipitate the development of professional management and advanced managerial practices because they affect the development factors of production in abundance and thus allows management and organizational specialization and development. Corporations also precipitate the emergence, sustenance, and development of professional managers by separating ownership from management.

\section{THE CASE OF GREECE}

During the nineteenth and twentieth centuries, industrialization became the basis of modern economic progress. Countries that were industrialized began to lead the world economy, while; on the other hand, those countries that were not sufficiently industrialized did not progress adequately and continued to have economic problems. Therefore, industrialization became an essential requirement for progress (Aionso-Martínez, 2008, p.38)

Industrialization Greece came about in the early 1960s and was followed by a rapid shift to post-Fordism in the late 1980s, well before a culture of contractual relationships and attendant modes of social solidarity were widely developed (Petmesidou, 2005, p.120). This event had a tremendous impact upon the lack of opportunity for merging small private organizations into larger ones, thus creating corporations and the formation of new, larger organizations in the corporate form (Zolotas, 1964). It should be noted that investments in manufacturing from developed nations inside and outside Europe had been limited and some experts indicated that the entrepreneurial inclination of the Greeks has been toward commerce, not manufacturing (Ellis, Psilos, Westebee \& Nicolaou, 1964).

In 1992 a short revival in manufacturing took place which provided impetus for exports, and many industries were able to compete internationally because they had the protection of a cheap currency that was devalued regularly. However, the euro brought an end to this policy, and companies based in Greece can compete internationally only by becoming more innovative, keeping down their costs, and increasing their productivity (Nakos \& Hajidimitriou, 2009, p. 74). De-industrialization precipitated the manufacturing value added share to gross domestics product (GDP) to decline from around 20 percent in the mid 1970s to less than 13 percent in the late 1990s (Bruton, 2006). This was a very hard blow against the economy and it was imperative that the balance of manufacturing/service shares in the composition of Greek output should be fruitfully shifted in favor of manufacturing. (Pitelis \& Antonakis, (2003, p. 544). Greek industrialization performance is to be found in the low GDP per capita, the deep and long economic recession, and the unfavorable influence of manufacturing trade. The preponderance of traditional, low technology, consumer goods sectors over high technology industries also affects the declining share of manufacturing (Louri \& Pepelasis- Minoglou, 2001, p. 407).

The de-industrialization in the late 1980s precipitated the decline of the formation of new corporations, the inability of existing ones to grow in size and strength, and the merger of small proprietorships and partnerships in order to form larger entities in the corporate form. The economy has been traditionally composed of a very large number of small private organizations. Statistical data in the early 1960s indicated that in $1959,52 \%$ of all enterprises had fewer than nine persons; $27 \%$ had from 10-19 persons; $14 \%$ had 20-25 persons, and .7\% had more than 50 persons employed (Ethniki Statistiki Ypiresia Ellados, 1962).

In the past the ownership of business organizations did not want an increase in organizational size because of the fear of losing control and power. The same situation prevails today. The business firms in Greece are mainly family-owned or controlled by a group of shareholders (Mavridis, 2002). Most business organizations remain small and play a limited role in the Greek economic life, whereas large sized enterprises, although comprising only $1 \%$ of the total number of firms (in all sectors), play a vital role in the Greek economy mainly because of exports and the development of its stock market (Mavridis, 2002). For the same exact reasons the same situation prevails in Latin America causing a strong negative impact upon the development of the region (Theodore, 2009, p.26). 
Lamentably, mergers have taken place only in a small number of business organizations. In Greece mergers are performed when (a) two or more previously independent companies are merged in any way, or (b) one or more persons who already control at least one company, acquires directly or indirectly the control of the whole or parts of one or more other companies (Tsagkanos, Georgopoulos, Siriopoulos \& Koumanakos, 2008 , p.189). In the 1960s practically all small and medium sized enterprises were managed by the owners who were adamantly opposed to any type of mergers (Syndesmos Ellinon Viomihanon, 1969); the same situation still prevailed in the first decade of the current century. The government made great efforts to convince small business owners to enter into mergers; however, these attempts were not successful (Economic Development Plan for Greece, 1968-1972, 1968). This movement was also supported by many academicians in Greece and abroad and was initially noted in the early 1960s (Damaskinidis, 196). Recent studies by the author of this work in Latin America also indicate the reluctance of Latin American entrepreneurs to enter into mergers because for both economic and cultural reasons (Theodore, 2011 p. 16).

In Greece corporations are controlled by a combination of government organizations and wealthy families (Dewenter \& Malatesta, 2001, p. 320). Close corporations in the past were reluctant to open in order to acquire more capital and develop themselves in all factors of production, including management (Alexander, 1964, p.108). In 1960, only 4\% of the private organizations were open corporations in the country (Ethniki Statistiki Ypiresia Ellados, 1960). Greek firms have been mainly family or controlled by a group of stockholders. Free float is relatively small in percentage $(20-50 \%)$ and the ability to achieve control through the capital market is limited (Lazarides \& Trimpetas, 2009). The majority of medium and small organizations (family-owned companies) have adopted the minimum mandatory requirements and lack further efficient corporate governance mechanisms (Spanos, 2005, p. 19).

In the late 1990s, the Greek government began the process of privatizing public companies. A necessary condition of creating a market economy is that of the state transferring its ownership and control factors of production to owners via the process of privatization which is essential for improving market efficiency because only a robust private sector can shape the relations between supply and demand leading to better production and consumption decisions (Daniels, Radebaugh, \& Sullivan, 2009). In 2011, the European Union presented a number of conditions Greece has to meet in order to justify the support received by the former. One of the conditions is the privatization of government corporations. This process is slowly but steadily being implemented. However, the chief executive officers (CEO) of government corporations in Greece do not either have the necessary experience or the commensurate education to manage private corporate organizations. Perhaps the most challenging task for top management, as it tries to leverage the overall performance of the corporation, is the need to coordinate the activities of an organization deliberately designed around diverse perspectives and responsibilities (Bartlett, 2008).

Since most Greek business organizations are small, this situation disallows the formation of an infrastructure that leads to the principles of organization - divisions, departments, positions, job duties, authority and responsibility, formal interaction, span of control, chain of command, and the delegation of authority and responsibility - and the development of management - decentralization, human relations, group dynamics, moving from Theory $\mathrm{X}$ to Theory $\mathrm{Y}$, and creating learning organizations and knowledge management, all of which necessitate the presence of the corporate form of business .

In the past most of the managers had to be members of the family of the owners (Papageorge, 1967). The same situation continues to the present time, in most cases. Family members of the controlling group occupy managerial positions, and normally there is no distinction between management and ownership. The managers who are not members of the controlling business family are also closely connected with these groups and their decisions are subject to family control and monitoring (Lazarides \& Drimpetas, 2009). Research done recently by Greek academicians on human resources selection indicated that selective hiring was found to be a key practice that improved organizational performance. Compensation policy, information sharing, decentralization of decision making, and extensive training were significant predictors for all performance variables (Vlachos, 2009, p. 26).

The mentality of the owners and managers and the small size of business organizations did not allow the development of the managers (Coutsoumaris, 1963). However today, due to the strong entrepreneurial tradition, policy-makers and managers need to examine the extent to which pro-activeness can build a fertile entrepreneurial 
environment which could respond easier to the emerging global competitive landscape (Sdrolias, Sirakoulis, Trivelas, \& Poulios, 2007).

The majority of Greek employees in the private sector until 1971 were male (Theodore, 1971). The situation is better now; statistical data provided by the Greek National Statistics Service (2004-2005) indicates that although women comprise just over half $(50.5 \%)$ of the Greek population they have only recently become $39 \%$ of the total working population. Unemployment rates are even more obvious: $16 \%$ for women compared to $6 \%$ for men (Bellou, 2009, p.7).

In industrial enterprises, only 13.5 of the employees had a high school or university education in the past (Ethniki Statistiki Ypiresia Ellados, 1968), whereas in all enterprises of the country, 35\% of the employees had only the mandatory education - nine years of education (Economic Development Plan for Greece 1968-1972, 1971). In 1967, out of all private Greek enterprises, only 70 of them employed persons who were also attending either high schools and/or universities (Statoudakis, 1967, p. 123). According to the Greek National Statistics Service's report on employment for the year 2004, 36.1\% of Greek manpower has attended at least secondary school, $43.2 \%$ high school, and the remaining $20.7 \%$ have gained, as a minimum, a college degree from a technological educational institute or a university (Bellou, 2009, p.16). In another study done by the present author in Latin America, the results indicate that the situation is very similar (Theodore, 2010, p. 31).

Innovation is limited in private enterprises and the country is lagging behind in the adoption/introduction of innovations and the development of business networks. One of the major elements in changing this situation is to stimulate and improve management and entrepreneurship (Hatzikian \& Bouris, 2007, p. 415). Research that was recently conducted in the Greek manufacturing sector indicated that the impact of human resource development on organizational performance is positive and serially mediated through skills, attitudes, and behavior and moderated by resourcing organizational context and other contingencies (Katou, 2009).

The most crucial factors, however, are the overall leadership qualities that the management of enterprises will be able to exhibit, which will establish the organization's vision for the future. In the Greek institutional context, the highly innovative companies with strong leadership were the ones to overcome country-specific barriers such as the low supply of technology, weak competitiveness, and the risk-averse national culture (Mertzanis, 2001, p. 93). The ever-increasing evidence of the country's failure to be competitive rests upon the lack of sufficient industrialization, and the weakness of micro-economic development that pivots around the strength of the corporate form of business that precipitates, sustains, and develops advanced organizational and managerial practices.

\section{CONCLUSIONS AND RECOMMENDATIONS}

Industrialization in Greece late in the early 1960s was followed by a de-industrialization process in the late 1980s. The country has been dominated by small proprietorships, partnerships, and non-stock corporations with limited factors of production that play a limited role in the generation of wealth in the economy.

For this reason, industrialization did not have the time, the power, and the support to generate, support, sustain, and develop the private corporate form of business which possesses all the factors of production in abundance that are needed for the creation and development of professional management.

\section{AUTHOR INFORMATION}

John Theodore is the holder of a Ph.D. degree in Administration and Latin American Studies from the University of Kansas; a Ph.D. in Management from the Aristotelian University in Greece, European Union; and a D.B.A. in International Business from the University of South Africa. He has been teaching and consulting for four decades domestically and internationally. He is a visiting professor in various foreign universities. Dr. Theodore is the president of JDT Management Consultants in Clearwater, Florida, specializing in management, organization, strategy, international business, human resources, organizational development, and educational administration. He is a certified management consultant (CMC) certified by the Institute of Management Consultants in Washington, D.C. E-mail: jdtheodore@tampabay.rr.com 


\section{REFERENCES}

1. Alexander, A. (1964). Greek industrialists. An economic and social analysis. Athens: Center of Planning and Economic Research.

2. Anderson, D. L. (2010). Organizational Development. The process of Leading Organizational Change. Los Angeles. Sage Publications, Inc.

3. Alonso-Martínez, C. (2008). Los modelos de Ddsarrollo tardios. Revista de Economía Mundial, (18), 5163. Retrieved from http://search.ebscohost.com/login.aspx?direct=true\&db=bth\&AN=34015128\&site=ehost-live

4. Apotelesmata Etisias Biomihanikis Erevnis etous 1959. (1962). Athinai: Ethniki Statistiki Ypiresia Ellados. Ekdosis A 4 Biomihania.

5. Bartlett, C., Ghoshal, S. \& Beamish, P. (2008). Transnational Management. $5^{\text {th }}$ Ed. Boston. McGraw-Hill Irwin.

6. Bellou, V. (2009). Profiling the desirable psychological contract for different groups of employees: evidence from Greece. International Journal of Human Resource Management, 20(4), 810-830. doi: 10.1080/09585190902770711

7. Bennis, W.G. (2009). The Essential Bennis. San Francisco. Jossey-Bass

8. Bruton, J. (2006). The European Union. Political, social, and economic cooperation.

9. Coutsoumaris, G. (1963). The morphology of Greek industry. Athens: Center of Economic Research.

10. Damaskinidis, A. (1963). Oikonomiki ton Epiheiriseon. Thessaloniki: Ekdotikos Oikos Adelphoi Zakouli.

11. Damaskinides, A. (1961). Synkrisis Ellinikos kai Europaikon Epiheiriseon en opsi tis endehomenis Syndeseos is Ellados me tin Europaikin Koinin Agoran. Meletai Europaikon Thematon. Thessaloniki: Europaiki Leshi Thessalonikis.

12. Damaskinidis, A. (1968). To Provlima tis Ekpaideuseos, kai idia tis Tehnikis, exetazomenon apo Oikonomikis Apopseos. Thessaloniki: Aristotelion Panepistimion Thessalonikis. Epistimoniki Epetiris Scholis Nomikon kai Oikonomikon Epistimon. Tomos AB.

13. Daniels, J., Radebaugh, L.H., \& Sullivan, D.P (2009). International Business, $20^{\text {th }}$ Edition. Upper Saddle River, NJ. Prentice Hall

14. Dewenter, K. \& Malatesta, P. (2001). State-owned and privately owned firms: An empirical analysis of profitability. American Economic Review 91 (1): 320.

15. Dialysmas, I. (1969). I poiotiki stathmi tis viomihanias. Athinai: Oikonomikos Tachydromos. Dioikisis Biomihanikon Epiheiriseon eis Hypoanaptiktous Horas. (1960) Athinai: Ellinikon Kentron Paragogikotitos

16. Ekpaidefsis Ypallilon Viomihanikon Epiheirison. (1961). Athinai: Ethniki StatistikiYpiresia Ellados.Ellis, H., Psilos, D., Westebee, R., \& Nicolaou, K. (1964). Industrial capital in Greek development. Athens: Center of Economic Research.

17. Fabun, D. (1973). The corporation as a creative environment. Beverly Hills, CA: Glencoe Press.

18. Gill, R. T. (1973). Economic Development: Past and Present. Englewood Cliffs, NJ, Prentice - Hall, Inc.

19. Hatzikian, Y., \& Bouris, J. (2007, December). Innovation management and economic perspectives: The case of Greece. Journal of Enterprising Culture, 15(4), 415.

20. Jones, G. R.\& George J.M. (2007). Essentials of Contemporary Management. $2^{\text {nd }}$ ed. Boston. McGraw-Hill Irwin.

21. Katou, A. A. (2009). The Impact of human resource development on organizational performance: Test of a causal model. Journal of Behavioral \& Applied Management, 10(3), 335-356. Retrieved from http://search.ebscohost.com/login.aspx?direct=true\&db=a9h\&AN=44537630\&site=ehost-live

22. Kreitner, R. (2007). Management. $10^{\text {th }}$ ed. Boston. Houghton Mifflin Company.

23. Lazarides ,T. G. \& Drimpetas, E. (2009), "Evaluating Corporate Governance and Identifying Its Formulating Factors: The Case of Greece", SSRN Working Paper Series, available at SSRN: http://ssrn.com/abstract=1317629

24. Lazarides, T., Drimpetas, E., \& Dimitrios, K. (2009). Ownership structure in Greece: Impact of corporate governance. ICFAI Journal of Corporate Governance, 8(3/4), 75-90. Retrieved from http://search.ebscohost.com/login.aspx?direct=true\&db=bth\&AN=42407667\&site=ehost-live

25. Louri, H., \& Minoglou, I.P. (2001). A quantitative exploration on the determinants of (de-)industrialization: the case of Greece. International Review of Applied Economics, 15(4), 407. doi:

10.1080/02692170110081930 
26. Mavridis G D (2002), "Marital Status Aspects Disclosed in Greek Interims Reports", Equal Opportunities International, Vol. 21, No. 8, pp. 1-17.

27. Mertzanis V. H. (2001), "Principles of Corporate Governance in Greece", Corporate Governance, Vol. 9, No 2, pp. 89-100.

28. Morck, R.K. (Ed.). (2007). A history of corporate governance around the world. Chicago, IL: University of Chicago Press.

29. Nakos, G.E., \& Hajidimitriou, Y.A. (2009, July-August). Conducting business in Greece: A brief for international managers. Global Business and Organizational Excellence, 74. doi: 10.1002/joe.

30. Palmer, I., Dunford, R., \& Akin, G. (2009). Managing Organizational Change. Boston. McGraw-Hill Irwin.

31. Papageorge, A.J. (1967). Transferability of management: A case study of the United States and Greece. Los Angeles: The University of California Press.

32. Pierce, J. \& Newstrom J. W. (2008). The Manager's Bookshelf. Upper Saddle River, NJ. Pearson Prentice Hall.

33. Pitelis, C., \& Antonakis, N. (2003). Manufacturing and competitiveness: the case of Greece. Journal of Economic Studies, 30(5/6), 544. doi: 10.1108/01443580310492826 Swindon, United Kingdom. PsySys Limited.

34. Spanos L J (2005), “Corporate Governance in Greece: Developments and PolicyImplications”, Corporate Governance: The International Journal of Business in Society, Vol. 5, No. 1, pp. 15-30.

35. Sdrolias L., Sirakoulis K., Trivellas P., Poulios T (2007). “Applicability of Project Management Tequniques in SMEs: Evidence From Greece”. Department of Project Management, TEI of Larissa, Greece.

36. Stratoudakis, P. (1967). Ta stelehi tis Ellinikis Viomihanias. Athinai. Ellinikon Kentron Paragogikotitos.

37. Theodore, J. (1971). I Exelixis tou Thesmou tis Dioikiseos ton Epiheiriseon eis Inomenas Politeias tis Amerikis kai i Parousa Katastasis os kai i Provlepomeni Exelixis tou Thesmou toutou eis tin Ellada. Athinai: Adelphoi Ioannidi

38. Theodore, J. (2009, July). Organizational size: A key element in the development of private enterprises in the less developed countries. The case of Ecuador. International Journal of Business \&Economics Research, 8(7), 45-49.

39. Theodore, J. (2010). Management education: A key element for the development of private enterprises in Latin America: The case of Ecuador. International Business \& Economics Research Journal, 9(2).

40. Theodore, J. (January, 2011). Mergers of private enterprises: A powerful force for the development of private business organizations in Latin America: The case of Ecuador. International Business \& Economics Research Journal (Volume 10, Number 1)

41. Tsagkanos, A., Georgopoulos, A., Siriopoulos, C., \& Koumanakos, E. (2008). Identification of Greek takeover targets and coherent policy implications. Review of Development Economics, 12(1), 180-192. doi: 10.1111/j.1467- 9361.2008.00436.x

42. Voulgaris, F., Asteriou, D., \& Agiomirgianakis, G. (2002). Applied Economics, 34, 1380. doi:

43. 10.1080/0003684011009682 2

44. Vlachos, I. (2008). The effect of human resource practices on organizational performance: evidence from Greece. International Journal of Human Resource Management, 19(1), 74-97. doi: $10.1080 / 09585190701763933$

45. Wren, D.A. (1994). The Evolution of Management Thought. New York. John Wiley and Sons, Inc.

46. Zolotas, K.E. (1964). I Ellas is to stadion Ekviomihaniseos.Seira Eidikon Melenton. Athinai,_Trapeza Ellados. 
NOTES 